December 2008

\title{
"Why are we learning this?": Does Studying the Holocaust Encourage Better Citizenship Values?
}

Henry Maitles

Follow this and additional works at: https://digitalcommons.usf.edu/gsp

\section{Recommended Citation}

Maitles, Henry (2008) "'Why are we learning this?": Does Studying the Holocaust Encourage Better Citizenship Values?," Genocide Studies and Prevention: An International Journal: Vol. 3: Iss. 3: Article 7. Available at: https://digitalcommons.usf.edu/gsp/vol3/iss3/7

This Articles is brought to you for free and open access by the Open Access Journals at Digital Commons @ University of South Florida. It has been accepted for inclusion in Genocide Studies and Prevention: An International Journal by an authorized editor of Digital Commons @ University of South Florida. For more information, please contact digitalcommons@usf.edu. 


\title{
"Why are we learning this?"': Does Studying the Holocaust Encourage Better Citizenship Values?
}

\author{
Henry Maitles \\ Faculty of Education, University of Strathclyde
}

\begin{abstract}
The relationship between learning about the Holocaust and the development of positive values may seem common sense, but in reality there is a complex level of development and understanding. The research reported here, which was sponsored by the Scottish government, was designed to ascertain whether learning about the Holocaust has an impact on young people's general citizenship values and attitudes; does learning about the Holocaust allow them to extrapolate from the events of the Holocaust to present-day issues, such as racism and discrimination? The study followed a cohort of approximately 100 pupils (aged 11-12) who had studied the Holocaust and compared their values one year later both to their earlier attitudes and to those of their peers who had not studied the Holocaust. As we might expect, the results were not always as predicted, particularly when it came to the pupils' understanding of anti-Semitism or genocide; in general, however, the study's core group maintained more positive values than they had before their lessons on the Holocaust and showed more positive values than their peers who had not studied the Holocaust.
\end{abstract}

Keywords: Holocaust, values, citizenship

\section{Introduction}

Education alone cannot be a panacea for racism in general and anti-Semitism in particular. Nonetheless, there has been some evidence in Britain that learning about the Holocaust can have a positive impact on the outlook of young people. ${ }^{1}$ The Holocaust has been taught piecemeal in Scottish primary and secondary schools for many years, depending on the individual initiative of the teacher, but the introduction of Holocaust Memorial Day in 2001 has made such teaching more mainstream and easier. In curricular terms, this was because the announcement of UK Holocaust Memorial Day was accompanied by the commissioning of curricular materials for teaching Holocaust history to primary pupils aged ten to eleven years, ${ }^{2}$ as well as a separate resource for secondary schools, ${ }^{3}$ which were later distributed to every primary school in Scotland in preparation for the first commemorative event. Both sets of resources make links with contemporary manifestations of racism, prejudice, and discrimination. The Scottish Executive has continued to fund curricular materials on the Holocaust. ${ }^{4}$

The content of these curricular resources shares a strong focus on the areas of knowledge and understanding relevant to the development of active and responsible citizenship. Currently a national priority, "Values and Citizenship" involves teaching pupils "duties and responsibilities of citizenship in democratic society" and "respect for self and one another." Further, the Education for Citizenship proposal, ${ }^{6}$ implemented from August 2003, has added impetus to the development of teaching about the Holocaust in schools. As in England and Wales, the proposal is for education for

Henry Maitles, “Why are we learning this?': Does Studying the Holocaust Encourage Better Citizenship Values?" Genocide Studies and Prevention 3, 3 (December 2008): 341-352. (C) 2008 Genocide Studies and Prevention. doi:10.3138/gsp.3.3.341 
citizenship to be an entitlement for all pupils at all stages. In Scotland, however, because of the cross-curricular scope of the 5-14 proposals (which cover the primary years and the first two years of the secondary curriculum), the existence of Modern Studies in the secondary schools, the development of Social Subjects in Environmental Studies in the primary schools, and the incorporation of "responsible citizenship" in the Curriculum for Excellence proposals, ${ }^{7}$ citizenship is not a separate subject but is taught in a cross-curricular approach. Despite some fears that the responsibility of all can become the responsibility of none, the suggestion is that many subjects will have input into education for citizenship.

In this citizenship agenda, the Holocaust is mentioned only as an example of the kinds of teaching content that could be employed, and the desire to develop positive attitudes toward other cultures, faiths, and ethnic groups means that a study of the worst genocide in history can be an important part of a child's development. Teaching about the Holocaust provides a suitable context for attainment in many key areas specified in proposals for Education for Citizenship in Scotland, including human rights and the need for mutual respect, tolerance, and understanding of a diverse and multicultural Scotland.

As a result of these curricular developments, government and local authority support, and research into Holocaust teaching, Scottish teachers in the upper primary and lower secondary stages now have more opportunities to teach the Holocaust and greater access to Holocaust teaching resources than before. Further, an additional $20 \%$ "flexibility time" allows schools to enhance the time spent on a curricular area for which they consider the minimum time insufficient and which has been prioritized for development by the school and the local authority.

However, we must remain aware that while education policy may stress positive values such as understanding, empathy, and tolerance, there can be a countervailing impact from other policy areas, such as economic and housing policies, the holding of terrorist suspects, and scaremongering (e.g., about numbers of refugees), that can produce effects opposite to the aims of the education policy agenda.

These countervailing issues have meant that despite increased education in the area, there are some worrying signs of increases in anti-Semitism, particularly in Europe: ${ }^{8}$ the Community Security Trust reporting that 2006 saw the highest-ever total of 594 reported incidents in Britain, of which sixteen were reported in Scotland. Further, there are some disturbing changes in the pattern of anti-Semitic activities, in that there have been large increases in number of violent assaults and in damages and desecration to property. ${ }^{9}$ It is important not to overstate the level of these activities, which do not reach the level of racism faced by some other ethnic minorities. While there are some worrying cases of continued neo-Nazi violence in these reports, there is debate over a new form of anti-Semitism in which hostile acts against Jewish targets are related to events in the Middle East.

\section{School-Based Holocaust Education}

In responding to pedagogical issues such as Jean Piaget's theories of children's intellectual and moral development, which suggest that children are unable to abstract and satisfactorily understand this kind of topic, Geoffrey Short and Carol Ann Reed cite a number of Piaget's critics who have influenced teachers to raise their expectations of children's abilities. ${ }^{10}$ The contribution of Holocaust education in the primary school includes developing pupils' understanding of justice, stereotyping, and discrimination, ${ }^{11}$ as well as providing opportunities for developing positive values of 
empathy, awareness of antiracism, and an understanding that the individual can make a difference.

A contrasting viewpoint is conveyed by Samuel Totten, on the grounds that the Holocaust is inappropriate and too complex for this age group to study, and by Lionel Kochan, who objects to its teaching to the "immature and unsophisticated," claiming that such teaching can have deleterious consequences for pupils. ${ }^{12}$ The former viewpoint is challenged by Cowan and Maitles in their case study of the response to Holocaust Memorial Day of an educational authority in which Holocaust teaching was already the norm for the upper primary classes (ages 10-12 years) and which provided a variety of appropriate curriculum materials and staff development. ${ }^{13}$ The latter viewpoint is challenged by the study reported here, together with its phase 1 study, which suggested that teaching the Holocaust has a positive short-term impact on pupils' values and attitudes. ${ }^{14}$ In this article, which presents some of the findings from three surveys, we suggest that evidence exists that further supports the teaching of the Holocaust to upper primary pupils.

Previous research in secondary schools ${ }^{15}$ provides evidence that Holocaust education can make a significant contribution to citizenship by developing pupils' awareness of human-rights issues and genocides and the concepts of stereotyping and scapegoating, as well as their general political literacy, including the exercise of power in local, national, and global contexts. Ronnie Landau asserts that Holocaust teaching, "perhaps more effectively than any other subject, has the power to sensitise [pupils] to the dangers of indifference, intolerance, racism and the dehumanisation of others."16 Short asserts that one of the lessons the Holocaust teaches pupils is that their own attitudes are, "to some extent, culturally determined" and that its teaching should encourage pupils to examine whether any harmful stereotypes may emanate from an aspect of their culture. ${ }^{17}$

Holocaust education is part of the English National Curriculum at Key Stage 3 (S1/2 Scottish equivalent age group, or 12-14 years of age), and there are currently debates as to its effectiveness. In particular, Lucy Russell suggests that history teachers are inconsistent in their methodologies, as some teach the Holocaust as history while others focus on the social and moral perspectives without applying historical inquiry. ${ }^{18}$ In Scotland, as we have pointed out, although there are plenty of opportunities in the curriculum for teaching about the Holocaust, too often "Holocaust teaching ... depends on individual school policy, and/or interested teachers" who integrate it into modes of the curriculum. ${ }^{19}$ Although the Holocaust is not specifically included in the Scottish curriculum, the 5-14 National Guidelines, or the new Curriculum for Excellence, there is plenty of scope and flexibility within this curriculum for teaching it. Traditional curricular areas are Religious and Moral Education, Environmental Studies, and Personal and Social Development.

A further concern relates to raising controversial issues in schools in the first place. In primary schools there is a perceived lack of specialist subject knowledge on the part of teachers. ${ }^{20}$ Paradoxically, a 2001 study of political consciousness in twentyeight European countries found that in many countries more specialized secondary teachers are similarly afraid to tackle controversial issues because, almost by definition, the discussion becomes multidisciplinary, and they are uncomfortable in that zone. ${ }^{21}$ However, in analyzing how high school students understood the place of classroom discussion, Carole Hahn found that students in the Netherlands did not try to persuade each other, even when discussing highly controversial issues that they felt strongly about, whereas in German and US public schools and in English private 
schools there was strong argument and persuasion. Interestingly, Hahn found that there was virtually no discussion on political issues in the state sector in England, even in social science classes, where she gathered that "the primary purpose was to prepare for examinations." 22 There are other general issues involved, affecting both school sectors, that militate against the discussion of controversial issues. First, teachers worry about their skill in handling open-ended discussions that they may not be able to control or direct. For example, it was reported that one school's history department "avoided selecting the Holocaust as a topic for GCSE coursework for fear of confronting anti-Semitic sentiment and Holocaust denial among some Muslim pupils." ${ }^{23}$ Second, there are structural constraints in schools, from the lack of tradition in discussion to the physical layout of classrooms. Third, there are worries about what parents might think about controversial discussions, and the fears expressed by some politicians and parents, and in the mass media, that such discussions will influence pupils one way or another. Discussions around sectarian issues are particularly problematic in Scotland because there exist strong religious and cultural identifications with both communities in Northern Ireland.

Alan Smith raises a further question: Can a concept of citizenship "based on equal rights and a shared sense of belonging ... moderate, transcend or displace identity politics and concepts of nationality?" ${ }^{24}$ And, as if this were not problematic enough, there is the point of limitations to compromise and consensus. Learning in this area suggests to pupils that there is not always a compromise available, no matter how hard we try, and it is this inability that leads to the kind of violent scenes we see on our TV screens and, sometimes, on our streets. This is a valuable lesson, and one that can be extrapolated to other conflicts (such as the war in Iraq) across the world. The role of the teacher becomes crucial here. As has been suggested elsewhere, the teacher needs to be confident enough and have the honesty and confidence to suggest to pupils that he or she is not just an independent observer but has a particular point of view, which also can and should be challenged. ${ }^{25}$ While this is an area of continuing discussion and debate in Britain, Terry Wrigley points out that in Germany, teachers are encouraged to allow discussion around controversial issues, to present a wide range of views, and to be open about their own standpoint while allowing for all views to be challenged. ${ }^{26}$ In the very slim curriculum guidelines in Denmark, teachers are encouraged not to "overplan," so that, in discussions with their pupils, issues deemed relevant for discussion can be included. Indeed, it is crucial, according to Elizabeth Ashton and Brenda Watson, that teachers understand their proactive role, where necessary; otherwise, backward ideas can dominate the discussion. ${ }^{27}$ Further, teachers must gently point out that the issues being discussed have not yet been resolved and are open-ended in terms of outcome. Pupils have little problem with this and are less dogmatic than adults when it comes to changing attitudes and political understanding.

\section{Methodology}

To investigate the value of Holocaust education, the author devised a longitudinal strategy that examined whether there are "immediate" and "lasting" effects on the attitudes and dispositions of pupils that result from Holocaust teaching; further, the values of this cohort were compared to their peers who did not have the opportunity to study the Holocaust in primary school. The results provide empirical evidence of the contribution of Holocaust education in developing positive attitudes relating to citizenship. 
This small-scale study involved some 100 pupils in Primary 7 (aged 11-12 years) and a total of 238 pupils in Secondary 1 (aged 12-13 years). In order to avoid aspects of familiarity, to move beyond the multicultural milieus where studies on this topic have most often been conducted, and to explore issues such as attitudes toward Gypsy Travellers and Jews, a small rural local authority some 30 miles from Glasgow was chosen for the study. The school sample was chosen in collaboration with the local authority, which identified two primary schools in the area that taught the Holocaust as part of the World War II topic in Primary 7. School A has only one class per year; School B, a larger school, has three classes in Primary 7. Both primaries are nondenominational, have socioeconomically mixed catchment areas, are predominantly white, and have no Jewish pupils; pupils at both schools go on to attend the same secondary school. Class sizes were similar in both schools.

In consultation with the schools and the local authority, a survey was devised that aimed to ascertain changes in some of the values and attitudes outlined as central in national documentation on citizenship. ${ }^{28}$ The survey was administered before and immediately after the lessons on the Holocaust, in November 2004 and March 2005, to investigate the immediate effect of Holocaust education on pupils' values and attitudes (Surveys 1 and 2).

Ten months after Survey 2, we followed this cohort into the secondary school and issued Survey 3 to compare pupils' attitudes with earlier findings. This survey was also administered to Secondary 1 pupils who had not previously studied the Holocaust, in order to compare their attitudes with those of the core group. The timing of Survey 3 fitted in with teachers' forward planning of Holocaust teaching and meant that the impact of the media coverage leading up to the national Holocaust Memorial Day could not influence the findings. It is worth noting that the number of anti-Semitic incidents reported in the United Kingdom during this period rose from 375 (2004) to $532(2005){ }^{29}$

Elsewhere we summarize the results of the first stage of our findings as follows:

It is important not to take too much from the first stage of this study. There is evidence that pupils' knowledge and values/attitudes improved (excepting pupils' attitudes towards English people) after their learning about the Holocaust. At the very least, numbers of pupils who put "don't know" for survey 1 came off the fence in survey 2 and came down in favour of tolerance and understanding. Yet, surprisingly few (only 28.3\% overall) knew (or thought they knew) what anti-Semitism was. Analysis of the ways in which teachers in our schools put the Holocaust in the citizenship context is likely to contribute to an understanding of this. For example, did teachers teach the Holocaust as a specific topic linked to genocide or as an example of racism per se? In terms of our general aims, the first stage suggests that there are some significant immediate benefits of learning the Holocaust; the longer lasting effects are yet to be ascertained and will be done so following our third survey. ${ }^{30}$

It is to this final point that we now turn. We obtained findings based on many more questions than are reported here; our principal interest at this stage of the study was to find out, first, whether the general improvements in knowledge and positive values and attitudes of the pupils after their learning about the Holocaust were maintained in the first year of secondary education; and, second, whether these pupils' understanding of the Holocaust and positive attitudes in aspects of citizenship were similar to or different from those of their peers who did not have an opportunity to study the Holocaust during primary school. 


\section{Findings and Discussion}

In terms of their own self-understanding, as Figure 1 shows, the core sample (those pupils who learned about the Holocaust in Primary 7) maintained their perception of their knowledge of the Holocaust and that it was substantially higher than that of others (their peers from primary schools that did not teach about the Holocaust). The fact that $61.9 \%$ of these other pupils knew about the Holocaust shows that there are opportunities-through the media, through other lessons, via Holocaust Memorial Day activities, or through parental comment_-for young people to find out about this topic; but the fact that nearly $40 \%$ did not recognize the term or know anything about it means that Holocaust education clearly has a major role to play.

A similar trend can be found in terms of perceived understanding of anti-Semitism. Only $3.5 \%$ of other pupils could define this term, whereas the proportion of the core sample who could do so stayed at approximately $22 \%$. Yet, although the core sample had a stronger understanding of this concept, perhaps the most significant factor is that there is such low awareness of the term overall. To investigate this question further, the author interviewed the teachers concerned. The teacher at School A developed lessons on the Holocaust without using this term; rather, she talked about "racism towards Jews." Similarly, Short's study of secondary students found that teachers were not including the critical role of anti-Semitism in their teaching of the origins of the Holocaust. ${ }^{31}$ While the teachers claimed that pupils understood what anti-Semitism was, despite not knowing the term, it is perhaps incumbent upon teachers to mention the terminology more clearly, so that pupils who come across media headlines relating to anti-Semitism will know what the story is about and relate it to their learning.

Similarly, there was very low awareness of the meaning of genocide on the part of other pupils, and, indeed, only $29 \%$ of pupils in the core group considered that they understood the meaning of this term. The findings suggest that teaching the Holocaust is a contributory factor to pupils' understanding of genocide, but only if the lessons

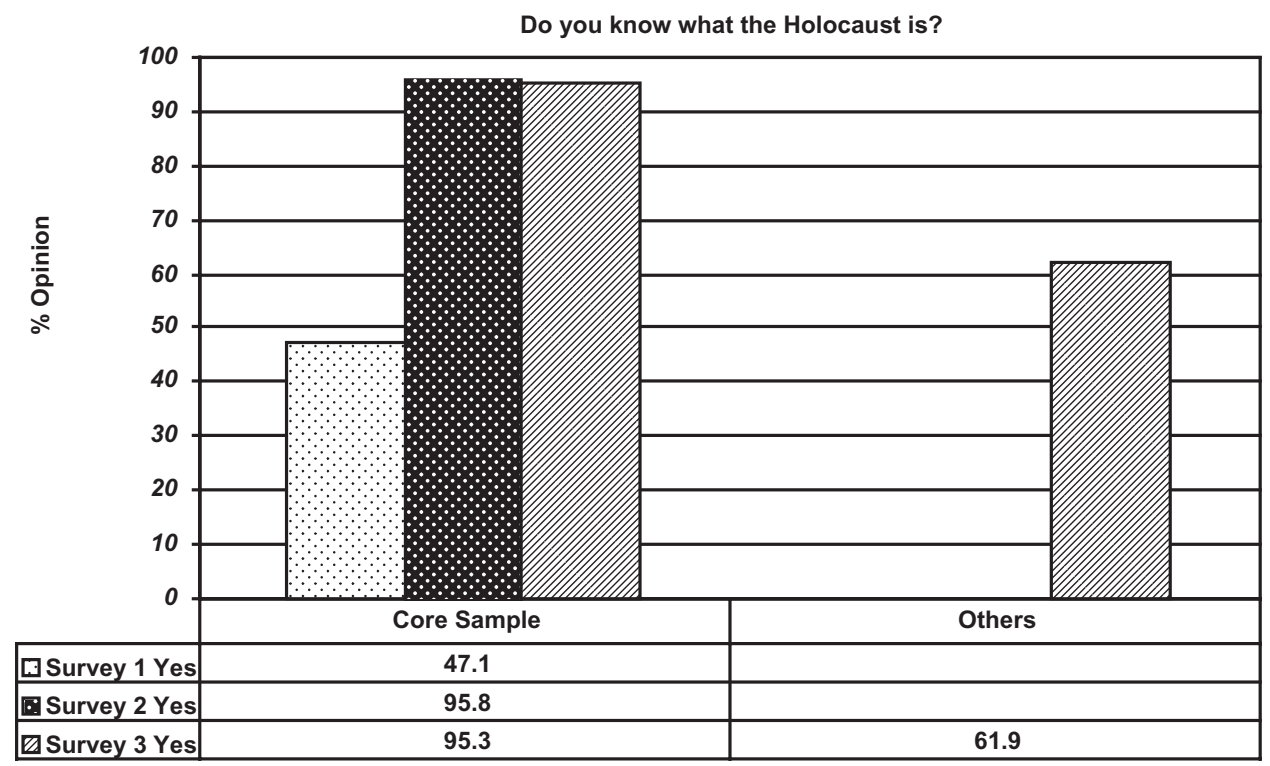

Figure 1. Pupils' perceived knowledge of the Holocaust 
make the links clear. Interview data show that School B included a great deal of content on the contemporary nature of the Holocaust, making relevant links with human-rights issues, introducing more recent genocides (in Bosnia, Rwanda, and Darfur), and discussing the current situation of refugees and asylum seekers in Scotland, while School A had only touched upon these contemporary links in a vague way.

These results have implications for the link between learning about the Holocaust as a historical event and contemporary issues relating to anti-Semitism and genocide. In particular, if one rationale for teaching the Holocaust in schools is to enable pupils to better understand contemporary genocide, ${ }^{32}$ the choice of teaching methodology and making explicit links become crucial.

Although there was a high level of agreement about not making racist comments, there was a more variable response to the statement "I think there are too many ... in Scotland" (see Figure 2). As Figure 2 shows, pupils' attitudes more or less remained where they had been after their lessons on the Holocaust; nonetheless, a much larger number of pupils claimed they were unsure. Interestingly, attitudes toward refugees held up better than the other variables, although this was the category that showed the most negative attitudes overall. The issue of refugees is a current one that was discussed both within and outside the classroom; it is unlikely that the other groups of people mentioned in the survey would have aroused similar interest.

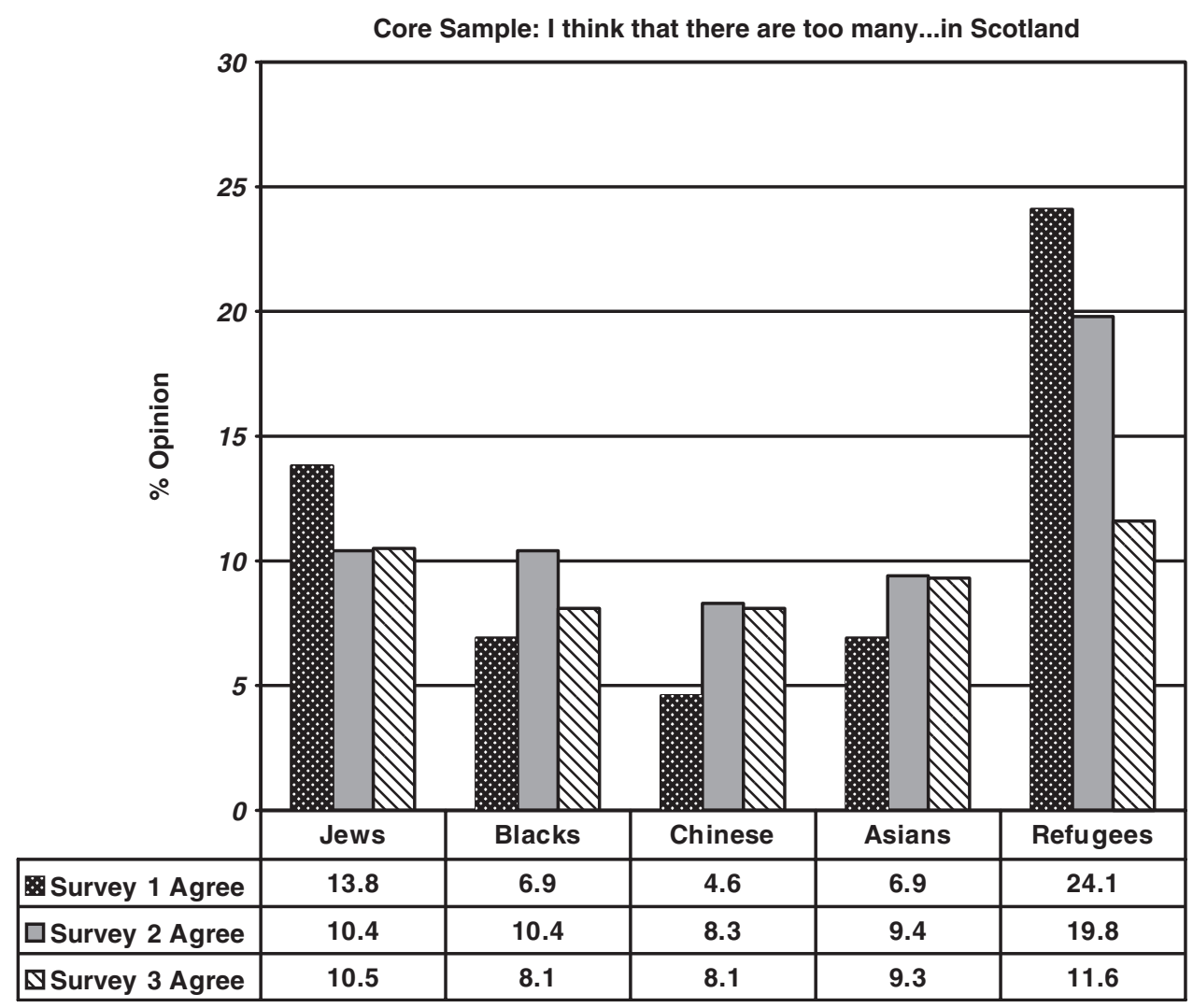

Figure 2. Opinions within the core group on the numbers of minority groups in Scotland 
Given that more than $95 \%$ pupils now consider that they know what the Holocaust is (see Figure 1), and that there are only about 5,000 Jews in Scotland, pupils' attitude toward Jews is rather puzzling: pupils' new knowledge appears to have had no longterm positive effect on their attitudes in this area. One possible explanation may lie in pupils' understanding of anti-Semitism. It may also be that anti-Semitism is perceived as something that happened in history and not as an issue relevant to contemporary Scottish society. It is also possible that pupils do not perceive Jews as an oppressed minority group in today's society. What we do know is that there was little discussion of the contemporary nature of anti-Semitism.

Another explanation may be found in Short's implication that successful Holocaust teaching is dependent on pupils' perceptions of Jews and Judaism and of the relationship between Judaism and Christianity. ${ }^{33}$ Data obtained from interviews show that School A had introduced Judaism in Primary 3 and studied another aspect of it in Primary 7, albeit after their teaching of the Holocaust; Primary 7 students at School B had studied Judaism the previous year. This suggests that pupils' perceptions of Jews, Judaism, and the Judeo-Christian relationship will have begun to form, but these perceptions were not examined in the present research.

Finally, it is feasible that the results may relate to the perceived differences between prejudice and discrimination; the pupils may have felt that there are "too many" minorities in Scotland but also believed that there should not be any abuse toward them.

One of the most contentious areas from the first stage of the survey was the voting potential of the sample and, in particular, the group's attitudes toward English people. While it is possible that pupils may have considered the Scottish Parliament an institution for Scottish people, irrespective of their ethnicity, we have previously concluded that

The research uncovered some anti-English feeling - the only area that significantly declined in the course of the two questionnaires. This requires further investigation and has two significant implications for teachers. Firstly, it raises a serious question as to whether anti-English feeling is endemic in Scottish culture. When the class teachers were notified of these results they were concerned and committed to acting upon this by including it in their education for citizenship programme. Secondly, if teaching the Holocaust and anti-racism suggests that the only victims are persecuted peoples [e.g.,] Jews, Gypsies, Tutsis, there can be a danger of ignoring prejudice against other peoples, [e.g.,] English people, Italians. ${ }^{34}$

A comparison of the three surveys (see Figure 3) show that the improvements found after learning about the Holocaust were generally maintained (e.g., attitudes toward voting for a Catholic versus a Protestant) or continued to improve (e.g., attitudes toward voting for a woman versus a man). An exception is pupils' attitudes to black people; although attitudes in this category were better in Survey 3 than in Survey 1, they had fallen back significantly from the position found in Survey 2. Interestingly, attitudes toward English people improved most of all, although, with $52.3 \%$ agreeing and $36 \%$ disagreeing that they would be as likely to vote for an English candidate as for a Scottish one, they were still significantly poorer than in any other category.

Comparing the core group to their peers in terms of voting preference, we found that in every category our core sample was more tolerant. This suggests that their Holocaust learning had an impact here.

Finally, Figure 4 compares our core sample with their peers in terms of the statement "I think racism has nothing to do with me." Survey 3 found a significant 
difference between the two groups: the core group had a more positive attitude in their answers to this question, suggesting that these pupils have a greater understanding of collective responsibility for racism than their peers who did not learn about the Holocaust.

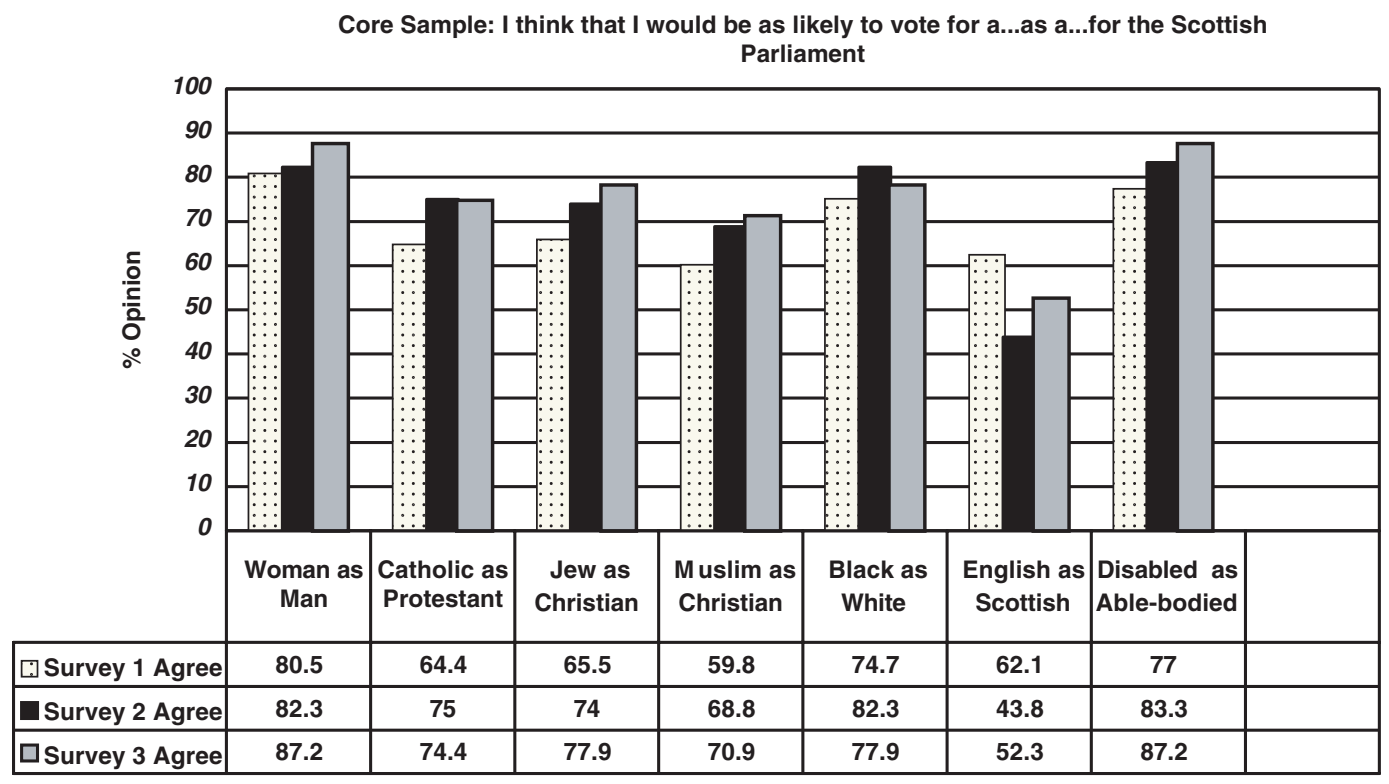

Figure 3. Voting attitudes

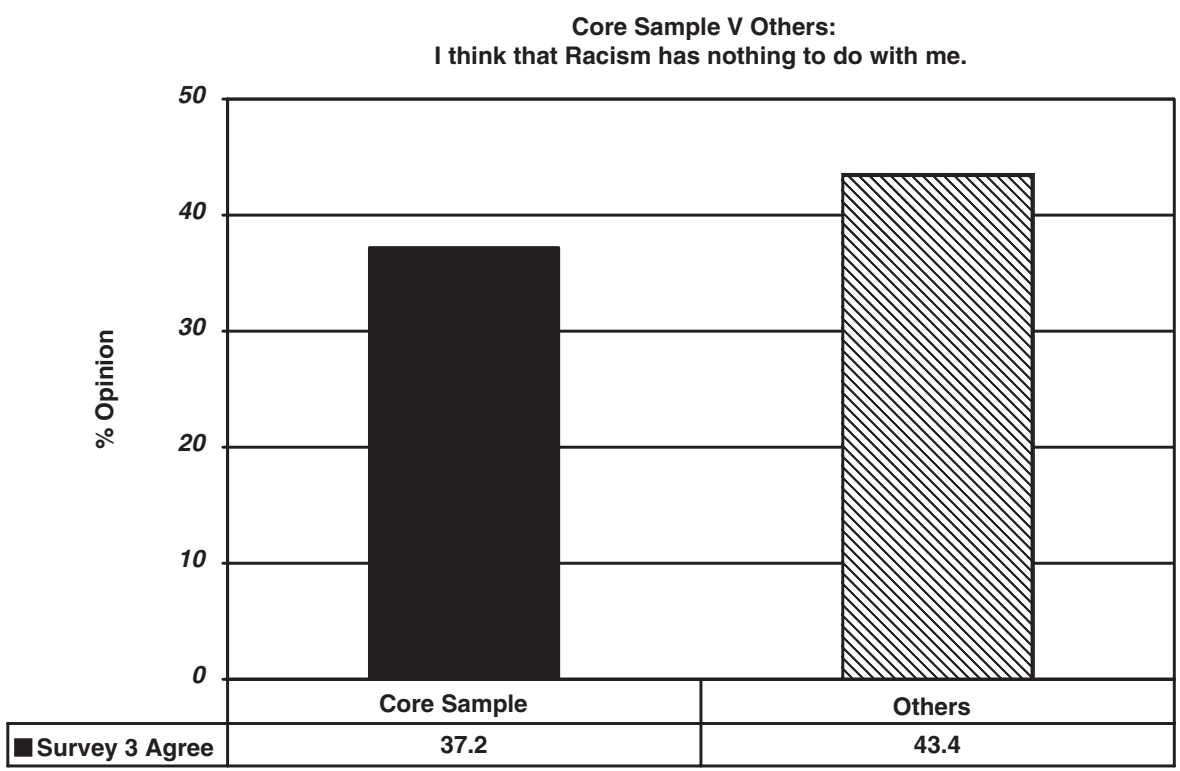

Figure 4. Comparison of core group and others on the statement "Racism has nothing to do with me" 


\section{Conclusions}

As in much research examining values and opinions, the results are not particularly clear-cut. In some areas, there does seem, less than one year on, to be a welcome maintenance of the positive dispositions ascertained in the immediate aftermath of the lessons on the Holocaust. Yet this effect remains uneven: our core group still had much tolerance for and sympathy toward minorities, but had "fallen back" in their opinion of the numbers of minorities in Scotland (perhaps reflecting a general increase in intolerance in British society). In most categories, however, attitudes were still better than they had been before the lessons on the Holocaust. There is still a worrying hostility toward English people, and this is something that needs to be watched and combated, although it may be that these pupils have a quite sophisticated understanding of the differences between oppressed and oppressors and that English people do not fit into the category of "oppressed." Another possibility, however, is that the idea of English people in the Scottish Parliament needed more explanation for these students. With hindsight—and for a future project—it might have been useful to ask about, for example, Polish or French candidates for the Scottish Parliament in this type of question.

When we compared our core group with their peers who had not had the opportunity to study the Holocaust, we found evidence, as outlined above, that the core group had stronger positive values, were more tolerant, and were more disposed to active citizenship because of their understanding of individual responsibility for racism.

This study suggests that learning about the Holocaust can have both an immediate and a lasting impact on pupils' values; that is, that studying the Holocaust teaches citizenship targets that are central to the development of well-rounded young people. It is worth making the case to teachers that at some stage in their education-perhaps as young as is deemed feasible-pupils should have the opportunity to undertake structured learning experiences about the Holocaust, generalized to reflect the various forms that racism can take in society and linking the Holocaust to other genocides. While the main focus of the research was not directly related to the training of teachers, there are clear implications for both initial teacher education and continuing professional development.

\section{Notes}

1. Bruce Carrington and Geoffrey Short, "Holocaust Education, Anti-racism and Citizenship," Educational Review 47 (1997): 271-82; Martin Brown and Ian Davies, "The Holocaust and Education for Citizenship," Educational Review 50 (1998): 75-83; Henry Maitles and Paula Cowan, "Teaching the Holocaust in Primary Schools in Scotland: Modes, Methodology and Content," Educational Review 51 (1999): 263-71; Paula Cowan and Henry Maitles, "Does Addressing Prejudice and Discrimination through Holocaust Education Produce Better Citizens?" Educational Review 59 (2007): 115-30.

2. Learning and Teaching Scotland [LTS], The Holocaust: A Teaching Pack for Primary Schools (Dundee: LTS, 2000).

3. Department for Education and Enterprise [DfEE], Remembering Genocides: Lessons for the Future (London: DfEE, 2000).

4. LTS, The Holocaust: A Teaching Pack for Secondary Schools (Dundee: LTS, 2002); Katherine Morley and Tim Nunn, The Arts and the Holocaust: Lessons from the Past for Citizens of Today (Barrhead: East Renfrewshire Council, 2002).

5. Standards in Scotland's School Act (2000) (Edinburgh: The Stationery Office, 2000), para. 4(1). 
6. LTS, Education for Citizenship in Scotland (Dundee: LTS, 2002).

7. Scottish Executive and LTS, A Curriculum for Excellence (Edinburgh: Scottish Executive, 2004).

8. Werner Bergmann and Juliane Wetzel, Manifestations of anti-Semitism in the European Union: Synthesis Report (European Monitoring Centre on Racism and Xenophobia, 2003), http://eumc.eu.int/eumc/FT.htm(accessed 11 April 2007); Community Security Trust [CST], Antisemitic Incidents Report 2006 (London: CST, 2007); European Union Agency for Fundamental Rights, Annual Report 2006: Situation Regarding Racism and Xenophobia in the Member States of the EU (FRA, November 2006), http://fra.europa.eu/fra/index.php?fuseaction $=$ content\&catid $=4491243 f 59$ ed9 $($ accessed 10 June 2007).

9. CST, Antisemitic Incidents Report 2006.

10. Geoffrey Short and Carol Ann Reed, Issues in Holocaust Education (Aldershot, UK: Ashgate, 2004).

11. Geoffrey Short and Bruce Carrington, "Unfair Discrimination: Teaching the Principles to Children of Primary School Age," Journal of Moral Education 20 (1991): 157-77; Maitles and Cowan, "Teaching the Holocaust"; Cowan and Maitles, "Does Addressing Prejudice."

12. Samuel Totten, "Should There Be Holocaust Education for K-4 Students? The Answer Is No," Social Studies and the Young Learner 12 (1999): 36-39; Lionel Kochan, "Life Over Death," Jewish Chronicle, 22 December 1989, 24. While Totten's article focuses on students aged five through nine, it expresses similar reservations about the ability of students in the upper elementary years to handle these complex issues.

13. Paula Cowan and Henry Maitles, "Developing Positive Values: A Case Study of Holocaust Memorial Day in the Primary Schools of One Local Authority in Scotland," Educational Review 54 (2002): 219-29.

14. Paula Cowan and Henry Maitles, "Values and Attitudes-Positive and Negative: A Study of the Impact of Teaching the Holocaust on Citizenship among Scottish 11-12 year olds," Scottish Educational Review 37 (2005): 104-15.

15. Carrington and Short, "Holocaust Education"; Brown and Davies, "The Holocaust and Education"; Geoffrey Short, Carrie Supple, and Kevin Klinger, The Holocaust in the School Curriculum: A European Perspective (Strasbourg: Council of Europe, 1998); Ian Davies, ed., Teaching the Holocaust (London: Continuum, 2000); Susan Hector, "Teaching the Holocaust in England," in Teaching the Holocaust, ed. Ian Davies, 105-15 (London: Continuum, 2000); Samuel Totten, "Diminishing the Complexity and Horror of the Holocaust: Using Simulations in an Attempt to Convey Historical Experience," Social Education 64 (2000): 165-71; Miriam Ben-Peretz, "Identifying with Horror: Teaching about the Holocaust," Curriculum Inquiry 33 (2003): 189-98; Silvan Schweber, "Simulating Survival," Curriculum Inquiry 33 (2003): 139-88.

16. Ronnie Landau, "No Nazi War in British History," Jewish Chronicle,25 August 1989, 6.

17. Geoffrey Short "Lessons of the Holocaust: A Response to Critics," Educational Review 55 (2003): 277-87.

18. Lucy Russell, Teaching the Holocaust in School History: Teachers or Preachers? (London: Continuum, 2007).

19. Maitles and Cowan "Teaching the Holocaust in Primary Schools," 265.

20. The Historical Association, T.E.A.C.H.: Teaching Emotive and Controversial History 3-19 (London: The Historical Association, 2007), http://www.history.org.uk/resources/resource_780.html (accessed 11 September 2008).

21. Judith Torny-Purta, Roger Lehmann, Henry Oswald, and John Amadeo, Citizenship and Education in 28 Countries (Amsterdam: International Association for the Evaluation of Education and Achievement, 2001).

22. Carole L. Hahn, Becoming Political: Comparative Perspectives on Citizenship Education (Albany: SUNY Press, 1998),49.

23. Historical Association, T.E.A.C.H. Report, 15.

24. Alan Smith, "Citizenship Education in Northern Ireland: Beyond National Identity," Cambridge Journal of Education 33 (2003): 15-31, 30. 
25. Faith Agostinone-Wilson, "Fair and Balanced to Death: Confronting the Cult of Neutrality in the Teacher Education Classroom," Journal for Critical Education Policy Studies 3, 1 (2005), www.jceps.com/?pageID=article\&articleID=37; Elizabeth Ashton and Brenda

Watson, "Values Education: A Fresh Look at Procedural Neutrality," Educational Studies 24 (1998): 183-93; Robert Stradling, "The Teaching of Controversial Issues: An

Evaluation," Educational Review 36 (1984): 121-29.

26. Terry Wrigley, Schools of Hope: A New Agenda for School Improvement (Stoke on Trent, UK: Trentham, 2003).

27. Ashton and Watson, "Values Education."

28. LTS, Education for Citizenship in Scotland; Scottish Executive and LTS, A Curriculum for Excellence.

29. CST, Antisemitic Incidents Report 2006.

30. Cowan and Maitles, "Values and Attitudes," 112-3.

31. Short, "Lessons of the Holocaust."

32. Short and Reed, Issues in Holocaust Education.

33. Geoffrey Short, "Holocaust Education in the Primary School: Some Reflections on an Emergent Debate," London Review of Education 1 (2003): 119-29.

34. Cowan and Maitles, "Values and Attitudes," 113. 